\title{
Tantangan globalisasi, peran negara, dan implikasinya terhadap aktualisasi nilai-nilai ideologi negara
}

\author{
Tatar Bonar Silitonga ${ }^{\text {a }}$ \\ a Manajemen Pertahanan, Universitas Pertahanan, Bogor, Indonesia
}

\begin{abstract}
ABSTRAK
Artikel ini bertujuan untuk menganalisis pengaruh globalisasi, peran negara, dan implikasinya terhadap aktualisasi nilai-nilai ideologi negara bagi Warga Negara Indonesia. Pendekatan yang digunakan dalam menjawab permasalahan adalah dengan studi literatur, observasi, dan wawancara. Dari hasil data ditemukan bahwa terdapat nilai-nilai globalisasi yang mempengaruhi pola pikir, sikap, dan perilaku sebagian warga negara yang didukung dengan konsistensi, ketegasan, dan penguatan peran pemerintah dalam merawat nilai-nilai kebersamaan. Selain itu juga berimplikasi untuk meredam eskalasi dan kegiatan yang menjurus pada perilaku yang menonjolkan sentiment primordial serta berimplikasi memantapkan persepsi warga negara tentang pentingnya ideologi negara, walaupun tidak langsung mengakselerasi masyarakat mengaktualisasikan nilai-nilai ideology negara secara signifikan.
\end{abstract}

\section{ABSTRACT}

This article aims to analyze the effect of globalization, the role of the state, and its implications for the actualization of state ideology values for Indonesian citizens. The approach used in answering problems is through literature study, observation, and interview. From the results of the data, it found that there are values of globalization that affect the mindset, attitudes, and behavior of some citizens supported by consistency, decisiveness, and strengthening the role of government in caring for the values of togetherness. It also has implications to reduce escalation and activities that lead to behaviors that highlight primordial sentiments and has implications for strengthening citizens' perceptions about the importance of state ideology. However, it does not directly accelerate the community to actualize state ideology values significantly.

\section{Sejarah Artikel}

Diterima : 2 Januari 2020

Disetujui: 3 April 2020

Kata kunci:

Globalisasi, peran negara, ideologi

\section{Keywords:}

Globalization, state, ideology

\section{Pendahuluan}

Ideologi negara sebagai perangkat gagasan atau konsep berpikir negara adalah sebagai tatanan nilai yang diharapkan dapat diaktualisasi dengan baik oleh negara yang direpresentasikan oleh pemerintah dan juga oleh warga negara. Ideologi tersebut pada dasarnya merupakan nilainilai yang disepakati bersama untuk dijadikan pedoman dalam bersikap dan berperilaku sebagai identitas negara serta seluruh warga negara. Ideologi sangat menentukan eksistensi suatu negara (Agus, 2016). Nilai-nilai yang dijadikan pedoman tersebut berisikan nilai-nilai yang baik dan diyakini mengantarkan bangsa memiliki peradaban yang membanggakan sekaligus membawa ke kehidupan ideal yang dicita-citakan dalam berbagai dimensi kehidupan meliputi bermasyarakat, berbangsa, dan bernegara. Ideologi memainkan peran sentral dan dibentuk sebagai kerangka kerja mental yang mendominasi pemikiran social suatu masyarakat (Li \& Soobaroyen, 2020).

Eksistensi ideologi oleh berbagai ahli biasanya dituntut untuk memperlihatkan sifat yang terbuka dan bukan tertutup. Asshiddiqie (2006) menjelaskan ciri dari dua tipe ideologi, pertama, ideologi tertutup diartikan sebagai ajaran yang kebenarannya tidak boleh dipersoalkan lagi, tidak hanya menentukan kebenaran nilai-nilai dan prinsip-prinsip dasar saja tetapi menentukan hal-hal yang bersifat konkret operasional, dan tidak bersumber dari masyarakat melainkan dari pikiran elite yang dipropagandakan kepada masyarakat. Sementara itu, ideologi terbuka adalah hanya 
berisi orientasi dasar, sedangkan penerjemahannya ke dalam tujuan-tujuan dan norma sosial politik selalu dapat dipertanyakan dan disesuaikan dengan prinsip moral yang berkembang di masyarakat (Asshiddiqie, 2006). Ideologi Pancasila berdasarkan pembedaan tipe ideologi tersebut, termasuk ke dalam jenis ideologi terbuka, setidaknya karena nilai-nilainya bersumber dari masyarakat Indonesia sendiri dan bukan pikiran elite yang dipropagandakan. Pancasila merupakan kristalisasi nilai-nilai budaya yang tumbuh dan berkembang dalam kehidupan keagamaan masyarakat (Mangunsong \& Fitria, 2019).

Eksistensi ideologi negara dalam konteks sistem nilai yang kuat dan teraktualisasi dalam pola sikap dan perilaku penyelenggara negara dan warga negara agaknya tidak selalu linier dengan upaya dan keinginan negara. Perjalanan negara dipenuhi dengan dinamika yang terjadi baik di internal negara, pengaruh eksternal, maupun interaksi dari keduanya. Kondisi tersebut dapat mengantarkan ideologi menjadi label patron saja. Konteks demikian mendapat kecaman Napoleon, bahwa ideologi sebagai khayalan tanpa arti praktis (Kaelan, 2004). Untuk itu menjadi penting agar ideologi teraktualisasi dalam sikap dan perilaku keseharian seluruh komponen bangsa. Hanya saja keberadaan Indonesia sebagai bangsa berinteraksi dengan kehidupan global yang ditandai dengan corak globalisasi.

Sassen (2007) berbicara mengenai gagasan globalisasi tentang saling ketergantungan satu sama lain, baik hubungan antar negara, negara dengan Non-Governmental Organization (NGO). Globalisasi merupakan fenomena beragam yang meliputi dimensi ekonomi, sosial, politik, teknologi dan budaya (Mir et al., 2014). Globalisasi dalam berbagai bentuknya secara langsung melibatkan dua asumsi utama. Dinamika kemajuan di berbagai bidang tersebut dalam realitanya telah memperlihatkan perubahan serta perkembangan lingkungan strategis yang berimplikasi pada kondisi-kondisi yang memberikan peluang dan kendala bagi kehidupan manusia. Namun dalam konteks ini, perspektifnya adalah pada dinamika kendala yang dilihat sebagai tantangan karena proses globalisasi dapat menghambat atau bahkan kontras dengan nilai-nilai bersama yang direpresentasikan dalam nilai-nilai Pancasila sebagai ideologi negara.

Hamilton melihat lebih fokus bahwa globalisasi sebagai integrasi perekonomian, teknologi, politik, budaya, dan aspek sosial antar negara di dunia. Integrasi tersebut berdimensi global mengambil bentuk lalu lintas koneksi yang bersifat bebas dan tidak terkecuali juga beragam nilai yang tidak koheren dengan nilai-nilai negara (Kemala, 2018). Berbagai nilai yang membonceng arus globalisasi seperti negara agama, negara sekuler, negara sosio demokrasi, paham radikalisme, fundamentalisme, komunisme, kekhalifahan, dan ateisme (Budiyono, 2017). Dengan begitu terbentuk internasionalisasi corak berpikir dan masyarakat dapat melihat dinamika perkembangan yang terjadi di luar negara.

Perkembangan yang terjadi tersebut menjadi lebih menarik bila dihubungkan dengan tesis Kenichi Ohmae yang menyebutkan bahwa batas wilayah secara geografi dan politik relatif tidak berubah namun berbeda dalam hal pembatasan terhadap akses global karena negara tidak dapat membatasinya (Ohmae, 1994; Wells \& Wang, 2017). Negara mestinya tidak takluk terhadap tantangan yang terjadi pada rakyatnya. Adanya negara sebagaimana disebutkan Soltau adalah agen atau kewenangan yang mengatur atau mengendalikan persoalan-persoalan bersama atas nama masyarakat (Budiarjo, 2017). Dalam hal ini dilihat pentingnya negara hadir untuk kepentingan masyarakat (Kiswanto, 2005; Novenanto, 2016).

Dengan kewenangannya, peran negara mengemuka dalam mendorong aktualisasi nilai-nilai ideologi negara. Nilai-nilai bersama bagi Indonesia adalah nilai-nilai Pancasila yang merupakan ideologi negara. Nilai-nilai tersebut tertuang di dalam kelima sila di dalam Pancasila, mulai Sila I sampai Sila V. Nilai-nilai ini tentu sudah tidak asing lagi dan secara umum sudah dipahami. Hanya saja bagaimana dengan praksisnya, kiranya hal inilah yang menjadi fokus dari pembahasan ini yang 16 
dikontekstualisasikan dengan dinamika tantangan globalisasi, peran negara, dan implikasi terhadap aktualisasi nilai-nilainya dalam kehidupan bermasyarakat, berbangsa, dan bernegara.

\section{Metode}

Pendekatan yang digunakan dalam memahami permasalahan yang diajukan adalah deskriptif analisis dengan studi kualitatif. Data-data dikumpulkan melalui studi literatur dan observasi. Studi literatur dilakukan dengan mengumpulkan data dari sumber referensi yang relevan seperti buku, artikel, dan perundang-undangan terkait, baik dari sumber tertulis maupun sumber digital. Kemudian observasi dilakukan dengan mengamati sikap dan perilaku penyelenggara negara serta masyarakat, termasuk dari sumber pemberitaan maupun spektrum interaksi sehari-hari. Hasil data studi literature dan observasi kemudian diperiksa kebermaknaannya yang relevan dengan aktualisasi nilai-nilai ideologi negara.

Merujuk pada objek bahasan, data-data yang dikumpulkan terkait nilai-nilai substantive sebagaimana termuat di dalam sila-sila Pancasila dan dikorelasikan hasil interaksinya dengan nilainilai yang berkembang sebagai konsekuensi dari proses globalisasi. Nilai-nilai yang berkembang meliputi berbagai paham yang dilihat sebagai nilai transnasional meliputi komunisme, sekularisme, fundamentalisme, pesimisme, animisme, individualisme, liberalism, hegemoni sektarianisme, kapitalisme, hedonism, dan nilai praktis.

\section{Hasil dan Pembahasan}

Globalisasi sebagai sebuah realitas tidak dapat dihindari. Globalisasi membentuk hubungan lintas negara dan lalu lintas tersebut memperlihatkan adanya ketergantungan satu dengan yang lain serta untuk saling membutuhkan dan melengkapi. Pada satu sisi, perkembangan telah memberi dampak positif dan negara dapat merasakan manfaatnya. Dengan perkembangan system teknologi, informasi, komunikasi, dan transportasi, negara diberikan kemudahan dalam melakukan berbagai kegiatan yang terkait dengan perencanaan, pelaksanaan, maupun evaluasi pelaksanaan pembangunan. Berbagai hal yang menjadi prioritas pemerintah baik pusat maupun daerah dapat dicermati masyarakat. Melaui media dengan mudah dapat dilihat serta diketahui hal-hal yang menjadi program pemerintah, baik dalam jangka panjang, jangka menengah, maupun jangka pendek. Dengan fasilitas sistem transportasi, pejabat pemerintah pusat misalnya dapat dengan mudah dan cepat melakukan peninjauan ke daerah. Hal-hal yang telah dilaporkan sebelumnya dapat dicek langsung di lapangan. Kemudahan yang sama dapat dilakukan, misalnya saja ketika suatu konflik meletus pada suatu wilayah, pemerintah dapat dengan segera mengirimkan tambahan pasukan pengamanan dari wilayah tertentu ke wilayah terjadinya konflik tersebut.

Realitanya globalisasi tidak hanya menawarkan dinamika dampak positif seperti gambaran di atas. Tidak dapat dinafikan berbagai permasalahan juga harus ditanggung negara terkait spektrum globalisasi tersebut yang dalam konteks ini dilihat sebagai tantangan. Berbagai nilai dengan identitas paham baik yang sudah lazim dikenal maupun yang mengambil bentuk baru, berseliweran menyertai tata pergaulan dan interaksi di tengah arus globalisasi. Setidaknya berbagai nilai dapat dilihat masyarakat dengan hubungannya dengan dunia maya serta akses terhadap informasi yang difasilitasi secara luas melalui internet. Teknologi internet membawa perubahan pada kehidupan manusia (Sanjaya, 2018). Dalam konteks politik misalnya, individu yang tertarik secara sosial dan politik sering menggunakan Internet untuk memfasilitasi dan meningkatkan partisipasi sipil dan politik mereka (Kim et al., 2011). Kondisi demikian dapat mempengaruhi corak berpikir baik masyarakat maupun penyelenggara negara. Hal ini sejalan dengan uraian yang menyebutkan bahwa di era globalisasi, rentan sekali masuknya nilai-nilai, norma, bahkan ideologi baru (Pratiwi et al., 2018). 
Dari dinamika lalu lintas pergaulan, interaksi, dan akses terhadap nilai-nilai yang berkembang, seperti apakah tantangan yang harus dihadapi negeri ini kiranya menarik untuk dilihat secara lebih rinci. Dalam hal ini bahasan dilakukan terhadap dua sub-fokus meliputi tantangan globalisasi dan peran negara yang dikorelasikan dengan implikasi aktualisasi nilai-nilai bersama. Pertama, tantangan yang dilihat pertama adalah bentuk pengaruh globalisasi terkait aktualisasi nilai-nilai ideologi yang ada pada masyarakat. Kemudian kedua, penelusuran juga dilakukan pada peran yang dilakukan oleh negara melalui representasi pemerintah dalam merespons tantangan globalisasi serta implikasi peran yang telah dimainkan pemerintah tersebut.

\section{a. Tantangan Globalisasi}

Tantangan yang dihadapi negara dalam konteks aktualisasi nilai-nilai ideologi sejauh ini adalah berkembangnya berbagai paham yang kurang sesuai dengan nilai-nilai ideologi Pancasila. Kondisi seperti itu menghasilkan adanya dialektik dan terjadinya tarik-menarik nilai di dalam diri warga negara. Warga negara di dalam memfilter berbagai nilai tersebut dipengaruhi oleh faktor yang ada di dalam dirinya, meliputi pemahaman dan kesadaran terhadap nilai-nilai bersama serta kondisi lingkungan. Kondisi lingkungan meliputi seputar masyarakat tempatnya berinteraksi maupun hasil koneksi dengan dunia maya. Berbagai tendensi yang diperlihatkan sebagian anak bangsa dalam bentuk pola pikir, sikap, dan perilaku yang kurang selaras dengan nilai-nilai kebersamaan seperti diamanatkan dalam ideologi negara, selanjutnya akan diuraikan dan dirinci berdasarkan urutan nilai yang termuat di dalam sila-sila Pancasila.

Pertama, tantangan dan implikasi aktualisasi nilai Sila Kesatu dari Pancasila pada diri anak bangsa, antara lain dapat dicermati atas hasil interaksi nilai spiritualitas Ketuhanan yang Maha Esa versus nilai komunisme/sosialisme, sekularisme, teokrasi, dan liberalisme. Spiritualitas sila Ketuhanan yang Maha Esa antara lain mengandung nilai dasar cita-cita kenegaraan dan nilai kesesuaian hubungan sebab akibat antara Tuhan, manusia, dan negara dan dalam hal itu setiap warga negara memiliki kebebasan dalam memeluk agama sesuai keimanan dan ketakwaan masing-masing (Kaelan, 2004, pp. 133-134). Sementara itu, komunisme/sosialisme merupakan paham yang meyakini bahwa kepemilikan modal dikuasai negara untuk kemakmuran secara merata (Nurwardani et al., 2016). Komunisme/sosialisme didasarkan pada sudut pandang materialisme dan terdapat ciri ateis karena manusia ditentukan oleh diri sendiri dan bukan terikat oleh kausalitas dengan Tuhan (Setijo, 2006). Sekularisme merupakan paham yang membedakan dan memisahkan antara agama dan negara (Kaelan, 2004, hal. 138). Teokrasi merupakan paham yang memandang antara negara dan agama tidak bisa dipisahkan (Kaelan, 2004, hal. 137). Liberalisme adalah paham yang berkembang dari akar rasionalisme serta individualism yang meletakkan nilai dan kebebasan individu sebagai nilai tertinggi dalam kehidupan bermasyarakat dan bernegara (Kaelan, 2004, hal. 142).

Tantangan aktualisasi nilai spiritualitas tersebut terkait adanya perspektif sebagian anak bangsa yang melihat alternatif ideologi agama bagi negara. Hal itu misalnya terlihat dari adanya pemikiran untuk membentuk negara khilafah dari sebagian kelompok masyarakat. Seiring dengan itu terdapat pula upaya pembatasan kelompok agama lain untuk membangun sarana rumah ibadah yang digunakan sebagai tempat untuk melaksanakan kegiatan agama. Budiyono (2017) mencatat kasus Ahmadiyah, konflik GKI Taman Yasmin, penutupan sejumlah gereja, dan pelarangan ibadah di beberapa wilayah. Sebaliknya terdapat pemikiran sebagai anggota masyarakat yang ingin melepaskan peran negara atas agama dalam konteks pemikiran bahwa agama menjadi ranah pribadi/privat setiap orang. Untuk yang terakhir ini, setidaknya peran negara di dalam urusan agama didorong untuk menjadi berkurang sehingga kemudian masyarakat dan individu yang menentukan soal-soal keagamaannya. 
Tantangan terhadap nilai sila kesatu Pancasila juga dapat dicermati dari dinamika agama KTP yang diperlihatkan sebagian anak bangsa. Secara identitas, mereka adalah beragama namun dari sikap dan perilaku keseharian memperlihatkan aktualisasi nilai yang bertentangan dengan seseorang yang beriman kepada Tuhan YME. Memang betul bahwa kualitas keimanan seseorang adalah lebih bersifat batiniah dan merupakan sesuatu yang dapat dinilai oleh hubungan personal antara diri seseorang dengan Tuhan yang diimaninya itu. Namun secara kasat mata, sebenarnya dapat dilihat pula aktualisasi dari nilai keberagamaan dari kemauan untuk mengikuti ritual/ibadah keagamaan dan toleran terhadap keberagaman dari keberagamaan. Setidaknya hal itu tergambarkan dari kemauan untuk menerima dinamika perbedaan dengan realisasi bahwa meskipun agama sendiri yang paling benar namun dipahami eksistensi dari agama lain.

Terkait aktualisasi nilai sila kesatu ini, meski sangat sulit ditemukan, tetapi bahkan ada juga yang sebetulnya tidak lagi mengakui keberadaan Tuhan atau istilah lain yang lebih dikenal sebagai penganut animisme. Sesuai tuntutan administrasi selaku warga negara, pada identitas diri (KTP) yang bersangkutan masih dengan status sebagai pemeluk agama tertentu, namun dihadapkan dengan realitas kepraktisan, orientasi diri sudah pada kemampuan diri sendiri dan condong pada paham materialis. Hal itu terjadi terutama dipengaruhi oleh sajian vulgar dinamika kehidupan global yang mempertontonkan hal-hal yang bersifat materi dan kebutuhan materi tersebut dipenuhi oleh anggota masyarakat sendiri. Kondisi ini sejalan dengan pendapat yang menyebutkan bahwa komunisme yang bersumber dari filsafat materialism melahirkan paham ateis (Surajiyo, 2018).

Selain itu, terlihat juga praktik keimanan sebagian anggota masyarakat yang mengartikan kehidupan beragama berada di ruang hampa. Pemahaman ini diartikan bahwa seakan tidak ada kelompok lain yang berada di ruang tersebut dan pemaknaan kebenaran agama secara hitam putih. Dengan begitu interaksi keberagamaan dimaknai dalam hubungan yang intens antara dirinya dengan Tuhan yang diyakininya. Selain itu, pemaknaan kebenaran secara hitam putih dalam pelaksanaannya menilai kebenaran hanya ada pada kelompoknya dan kelompok lain adalah sebagai musuh yang harus dilawan dan bahkan dihancurkan. Untuk pemahaman yang terakhir ini kemudian ditandai dengan eksistensi paham radikal dengan kegiatan modus bom bunuh diri atau pengeboman dengan sasaran kelompok yang dinilai sebagai kelompok hitam.

Dengan modus yang hampir sama, pelarangan kelompok tertentu melaksanakan kegiatan ibadah atau bahkan perusakan rumah ibadah sebagaimana kegiatan yang terjadi beberapa kali juga menjadi contoh aktualisasi nilai negative dimaksud. Jika demikian, tidak heran dinamika pandangan pemahaman toleransi yang telah bergeser dari hakikatnya. Dalam pengertian yang umum, toleransi dimaknai sebagai sikap dan perilaku saling memberi dan menghargai, berlangsung dua arah. Sikap dan perilaku bagi sebagai anggota masyarakat cenderung memaknai toleransi secara searah yaitu tuntutan orang lain memberikan penghargaan kepadanya, antara lain atas dasar kebenaran dan kebesaran kelompok.

Kedua, tantangan dan implikasi aktualisasi nilai sila kedua dari Pancasila pada diri anak bangsa, antara lain dapat dicermati atas hasil interaksi Nilai Kemanusiaan yang Adil dan Beradab versus fundamentalisme dan sektarian. Sila kedua ini antara lain mengandung nilai pengakuan atas hakikat kodrat manusia baik sebagai makhluk individu maupun makhluk sosial dan dalam hal itu bangsa Indonesia mengakui sebagai bagian dari umat manusia. Pancasila mengandung nilai humanis (Sitorus, 2016). Tantangan aktualisasi nilai sila kedua adalah pengakuan atas hak-hak asasi manusia. Hak untuk mendapatkan informasi, hak untuk mendapatkan penghormatan atas martabat diri, dan juga hak untuk beribadah sesuai keimanan seseorang termasuk nilai yang seharusnya dijamin. Era keterbukaan informasi sekarang ini dimaknai secara bebas tanpa batas, sehingga tercatat beberapa hasil dari perilaku perundungan, persekusi, dan menghujat orang. 
Tantangan pelaksanaan sila kedua ini juga terlihat dari pandangan nilai kemanusiaan sebagian dari anggota masyarakat adalah dari perspektif kelompok sehingga terkesan menjadi terkotak. Ketika melihat seseorang atau kelompok mendapatkan perlakuan yang tidak adil dari perlakuan harga diri dan kemanusiaan, maka penilaian dilakukan atas dasar apakah yang mendapatkan perlakuan tidak adil itu termasuk dalam kelompok sendiri atau bukan. Jika sudah begitu, praktik yang dilakukan pasti tidak jauh dari itu, yaitu pemberian penghargaan harkat dan martabat kepada orang lain yang didasarkan pada apakah orang tersebut sama dengan kelompoknya. Padahal harkat dan martabat kemanusiaan itu bersifat universal, namun dalam konteks ini telah dilakukan pengotakan seakan kemanusiaan itu dilihat dari siapakah manusianya. Hampir sama dengan itu adalah aktualisasi pola sikap dan perilaku tenggang rasa yang didasarkan atas siapakah pihak yang perlu diberikan tenggang rasa. Artinya dalam hal ini tenggang rasa diukur dari rasa sendiri dan bukan dari perspektif nilai umum kemanusiaan.

Tantangan yang juga perlu mendapatkan perhatian adalah terdapatnya sebagian anggota masyarakat yang kurang menjaga martabat dirinya. Plagiarisme nantinya terkait pula pada soal nilai sila kelima, namun dalam konteks ini kegiatan plagiarisme di lingkungan pendidikan menjadi aktualisasi dari kurangnya rasa harga diri antara lain misalnya menjiplak karya orang lain atau sekadar menyisipkan nama untuk diikutkan dalam proses publikasi padahal yang bersangkutan secara jelas-jelas tidak terlibat di dalam penyusunan naskah. Menjilat dan mengambil muka termasuk dari model kurangnya rasa harga diri tersebut. Sikap melebih-lebihkan bangsa lain dan merendahkan bangsa sendiri termasuk dari tantangan terhadap nilai ini. Hal ini sangat kontras dengan nilai paham chauvinisme yang begitu yakin akan kehormatan dan harga diri suatu bangsa. Dengan keberadaban, mestinya semua berpikir bahwa semua bangsa adalah memiliki harkat dan martabat sama.

Tantangan yang tidak kalah pentingnya adalah pada dinamika terorisme yaitu adanya sebagian anggota masyarakat yang terjebak dalam pola pikir dan tindak radikalisme. Pengaruh corak berpikir seperti ini masih ada kaitannya dengan nilai sila pertama maupun nilai sila-sila lainnya. Namun dalam perspektif ini, pelaku teror dan yang terlibat dalam paham radikal dalam implementasinya mengabaikan nilai-nilai kemanusiaan karena dalam operasionalnya menghancurkan kemanusiaan dan membuat rasa takut. Peledakan bom dan bom bunuh diri yang terjadi di berbagai tempat di Indonesia adalah menjadi merupakan bukti dari pengabaian nilai-nilai kemanusiaan dimaksud.

Ketiga, tantangan dan implikasi aktualisasi nilai sila ketiga Pancasila pada diri anak bangsa, antara lain dapat dicermati atas hasil interaksi nilai Persatuan Indonesia versus nilai hegemoni komunitas, dan pesimisme. Sila Ketiga ini mengandung nilai kebersamaan dengan keragaman dan terikat dalam kesatuan integral sebagai suatu bangsa yang merdeka bernama Indonesia. Dalam hal itu dipahami keanekaragaman keindonesiaan meliputi manusia, keluarga, kelompok, golongan, suku bangsa, keragaman wilayah, namun menjadi satu kesatuan integral baik lahir maupun batin (Kaela, 2004, hal. 130). Sementara itu hegemoni sektarian/ komunitas adalah paham yang didasarkan pada pemikiran kelompok tertentu dengan label sebagai komunitas mayoritas memiliki keeksklusifan.

Tantangan aktualisasi nilai sila ketiga terlihat dari orientasi persatuan sebagian anggota masyarakat dari perspektif kepentingan kelompok. Selain itu, aktualisasi orientasi etnisitas juga menjadi bagian bentuk perilaku yang perlu mendapatkan perhatian. Bukti dari corak berpikir seperti itu misalnya dari kegiatan yang dilakukan sebagian dari masyarakat yang lebih mementingkan kelompoknya daripada keindonesiaan secara umum. Kemudian ada pandangan bahwa masyarakat dari negara lain malah dirasa lebih memiliki kedekatan emosional daripada masyarakat yang ada di negara sendiri. Hal ini menjadi perwujudan dari corak globalisasi dengan 
ciri internasionalisasi, batas-batas negara lebih ke pengertian politis sementara paham masyarakat melampau batas-batas negara.

Tantangan lainnya dari Sila Ketiga bahkan dalam orientasi yang lebih ekstrem lagi, yaitu menganalogikan negara sebagai agama dalam perspektif baru. Individu atau kelompok yang memiliki konsep berpikir analogi seperti itu, sudah terdoktrin hanya bisa menerima aturan-aturan atau ketentuan yang ada kesesuaiannya dengan ajaran agama. Jika sudah begitu, ketika kelompok ini dihadapkan dengan otoritas negara yang mengatur tata hidup masyarakat, maka negara diidentikkan sebagai agama. Padahal pada saat sama yang bersangkutan telah memiliki agama, sehingga hadirnya negara yang tidak sesuai dengan nilai-nilai agama menjadi kurang diterima otoritasnya. Tidak terkecuali keberadaan symbol-simbol negara pun dinilai tidak perlu dan cenderung untuk diabaikan. Gambaran ini antara lain direpresentasikan oleh adanya sebagian masyarakat yang tidak mau mengikuti upacara dan penghormatan bendera. Orientasi seperti ini terasa sulit dipahami secara rasional, tetapi atas nama keyakinan bagi mereka hal seperti itu bukanlah sesuatu yang dirasa aneh, bahkan bagi mereka perlu untuk ditegakkan.

Keempat, tantangan dan implikasi aktualisasi nilai sila keempat dari Pancasila pada diri anak bangsa, antara lain dapat dicermati atas hasil interaksi nilai kerakyatan yang dipimpin oleh hikmat kebijaksanaan dalam permusyawaratan/perwakilan versus nilai liberalism dan hegemoni sektarianisme. Sila keempat ini mengandung nilai penghormatan terhadap demokrasi disertai tanggung jawab kepada Tuhan yang Maha Esa, menjunjung dan memperkokoh persatuan dan kesatuan bangsa, serta tujuan untuk mewujudkan kesejahteraan dalam hidup bersama. Tantangan aktualisasi nilai sila keempat terlihat dari praktik politik identitas, politik irasional, dan politik uang. Politik identitas adalah praktik demokrasi yang didasarkan pada sentiment primordial. Dalam berbagai kesempatan masih terlihat adanya elite politik yang mengajak masyarakat untuk memilih tokoh dengan dasar etnisitas seakan bila masyarakat memberikan hak pilih bukan dengan dasar itu terkesan demokrasi tidak berkeadilan. Pada perspektif tertentu, implementasi model ini termasuk sebagai pelaksanaan paham hegemoni sektarian/komunitas.

Pemilihan calon anggota legislative atau pejabat public lainnya atas dasar etnisitas bukan satu-satunya isu praktik politik identitas. Perjuangan tentang isu-isu dan kepentingan kelompok sendiri menjadi menu keseharian orasi dan aspirasi politiknya. Terbitnya berbagai peraturan daerah dengan sentimen diskriminatif dan tidak sesuai dengan nilai-nilai bersama, menjadi bentuk praktik dari hasil perjuangan politik identitas. Termasuk di dalam kriteria politik identitas juga terlihat dari perilaku upaya melakukan pemaksaan kehendak terhadap pihak lainnya. Dalam hal ini masih ada kaitannya dengan pengabaian sila kedua, pemaksaan kehendak terjadi saat adanya kelompok yang melarang masyarakat untuk mengikuti suatu kebijakan tertentu atau sebaliknya mewajibkan untuk melakukan sesuatu meskipun itu bukan merupakan kebijakan yang dikeluarkan secara nasional oleh pemerintahan yang sah.

Sementara itu politik irasional adalah praktik demokrasi yang memiliki keinginan memaksakan kehendaknya meskipun hal itu berlawanan dengan rasionalitas secara umum. Corak lain dari praktik politik irasional adalah pandangan yang penting vocal dan kritis meski realitas factual berbeda bukanlah masalah bagi pelaku politik irasional. Mengapa hal itu terjadi lagi-lagi dipengaruhi oleh berpikir sectoral atau pandangan tentang kepentingan kelompok. Bila ditelusuri lebih jauh, politik irasional diakibatkan oleh rasa frustrasi atas sistem atau kondisi yang ada. Melihat konstelasi dan peluang, rasanya sulit bagi kelompoknya untuk memenangkan kontestasi. Maka tidak ada pilihan lain, cara yang kemudian ditempuh adalah melakukan hal-hal yang "berani" atau mengandung kontroversi. Contoh lebih konkret di kehidupan anak bangsa, maju dalam pemilihan legislative atau eksekutif meski sudah terindikasi sebagai pelaku korupsi. 
Politik uang merupakan bentuk praksis yang ditunjukkan sebagian anak bangsa yang biasanya maju untuk dipilih dalam ajang pemilihan anggota legislative atau eksekutif. Dalam rangka agar terpilih dalam kontestasi, mereka mengucurkan dana untuk diberikan kepada konstituen yang menjadi sasaran dan diharapkan memilih calon pemberi dana. Politik uang dilakukan dalam versi pemberian uang secara langsung dengan nominal tertentu dan atau dalam acara kegiatan tertentu seperti memberikan sumbangan penyediaan sarana prasarana yang dinilai berguna bagi masyarakat. Beberapa dari antaranya, melakukan proses "investasi" pemberian bantuan tersebut bahkan dilakukan jauh-jauh sebelumnya.

Kelima, tantangan dan implikasi aktualisasi nilai sila kelima dari Pancasila pada diri anak bangsa, antara lain dapat dicermati atas hasil interaksi nilai Keadilan Sosial bagi Seluruh Rakyat Indonesia versus nilai kapitalisme, hedonisme, dan individualism. Sila Kelima ini mengandung nilai keadilan untuk mewujudkan hidup bersama baik bermasyarakat, berbangsa, maupun bernegara. Tantangan aktualisasi nilai sila kelima, terlihat dari pola peran kaum pemilik modal dalam menguasai pasar sehinga masyarakat kelas bawah dengan nota bene bermodal kecil semakin terpinggirkan. Tantangan terhadap nilai ini juga ditunjukkan melalui perilaku hedonis sebagian masyarakat. Bergaya hidup boros menjadi bagian pelengkap dari perilaku hedonis tersebut.

Ironisnya sebagian masyarakat terkesan memaksakan diri untuk masuk dalam pola hidup mewah tersebut sehingga memunculkan praksis melakukan jalan pintas atau menyalahgunakan wewenang seperti melakukan korupsi. Faktor materialism ikut berpengaruh dan terus-menerus mengikis nilai-nilai luhur masyarakat (Juneman et al., 2012). Terkait ini, kejahatan korupsi telah mengakibatkan kehancuran perekonomian bangsa (Bunga et al., 2019). Selain itu, masyarakat banyak menderita karena perilaku korupsi antara lain kehilangan lahan, pekerjaan, dan tanah kelahiran (Muryanti, 2018). Lalu praktik penipuan jual beli bukanlah terasa asing lagi. Perilaku hedonis dan terjerat dengan pola konsumerisme Ini erat kaitannya dengan tayangan vulgar perilaku gaya hidup di era global sekarang ini yang kemudian ditiru oleh sebagian masyarakat.

Selanjutnya, terdapat juga bentuk perilaku yang kurang memperlihatkan penghargaan terhadap fasilitas umum yang seharusnya menjadi milik bersama dan juga kurangnya etos kerja. Aksi corat-coret di jembatan, di dinding gedung, atau tempat-tempat umum sering ditemukan di seputar kehidupan masyarakat. Membuang sampah di sembarang tempat, merokok sembarangan, dan kurangnya kepedulian menjaga fasilitas umum adalah gambaran lainnya. Lalu plagiarisme atau membajak karya orang lain juga menjadi bagian contoh dari sikap dan perilaku anak bangsa yang tidak sesuai dengan nilai menghormati hak cipta orang lain. Rendahnya etos kerja termasuk dalam bagian ini, terkesan pekerja harus diawasi baru berkinerja tinggi. Padahal praktik demikian jelas jauh dari nilai-nilai suka bekerja keras dan juga mengurangi inovasi serta kreativitas diri. Pada era global sangat jelas tuntutannya yaitu daya saing yang hanya dapat dipenuhi melalui prasyarat adanya etos kerja, inovasi, dan kreativitas.

Jika dicermati berbagai pola pikir, sikap, dan perilaku yang tidak sesuai dengan aktualisasi nilai-nilai ideologi Pancasila tersebut, substansi nilai dipengaruhi oleh internasionalisasi paham global. Individualisme, komunisme, kapitalisme, individualism, liberalism, dan sektarianisme kiranya menjadi paham global yang ikut mempengaruhi sebagian masyarakat. Khususnya tentang paham agama, identitas primordial pada umumnya memiliki loyalitas kuat dan langgeng atau bertahan lama, serta melahirkan solidaritas erat (Winarno, 2014). Ketika paham agama tersebut kemudian diaktualisasikan dalam konteks negara seperti Indonesia dengan dinamika etnisitas yang sangat beragam, tentu saja akan menuai permasalahan tersendiri.

Secara lebih jauh lagi, berdasarkan dinamika keberagaman yang ada pada masyarakat dengan sendirinya akan mengonstruksi corak berpikir yang beragam pula. Jika diilustrasikan 
sebagai suatu benda yang berisikan muatan maka di dalamnya terdiri atas berbagai lapisan meliputi identitas diri, komunitas keluarga, komunitas lingkungan, etnisitas, kerangka negara bangsa, dan juga nilai-nilai global. Jika melihat prosedur penilaian moralitas dari Bertens (2000), nilai dalam kerangka bangsa dan negara lebih dekat pada prosedur hati nurani dan kaidah emas. Nilai-nilai lainnya terutama komunitas dan etnisitas, lebih banyak didasarkan penilaian umum yaitu umum menurut perspektif kelompok mana yang menilai. Nilai-nilai tersebut saling berhimpitan satu dengan yang lain dan satu hal perlu dicatat bahwa individu anggota masyarakat itu sendiri yang berkompeten dalam menentukan dirinya dominan pada nilai yang mana.

Dalam perspektif yang lain, berbagai aktualisasi nilai yang tidak sesuai nilai bersama sebagai bangsa yang ditunjukkan sebagian anak bangsa, meski terkesan minor namun dimensi etnisitas patut mendapatkan perhatian tersendiri. Perspektif etnisitas jika dibiarkan dapat mengganggu kohesivitas kehidupan bersama. Dalam eskalasi yang massif, perilaku tersebut dapat mengganggu integrasi nasional. Negara diharapkan dapat memainkan perannya untuk mengatur hubungan masyarakat serta bila diperlukan dapat melakukan monopoli atau tindakan memaksa atas nama keamanan negara (Budiarjo, 2017). Secara konsep prosedural, fungsi negara tersebut mudah, namun ketika dihadapkan dengan dinamika perkembangan yang terjadi, tidak dapat dinafikan kompleksitasnya.

Berbagai aktualisasi nilai-nilai yang kurang selaras dengan nilai-nilai Pancasila seperti telah diuraikan tersebut di atas dapat diringkas pada tabel berikut:

Tabel

Aktualisasi Nilai Kurang Sesuai dengan Nilai-nilai Ideologi Negara

\begin{tabular}{|c|c|c|c|}
\hline No. & Nilai-nilai & Tantangan & Aktualisasi Pola Pikir/Perilaku \\
\hline 1. & Sila I & $\begin{array}{l}\text { Nilai spiritualitas keagamaan } \\
\text { versus nilai komunisme, } \\
\text { sekularisme, fundamentalisme, } \\
\text { dan animisme }\end{array}$ & $\begin{array}{l}\text { Wacana negara khilafah } \\
\text { Wacana negara sekuler } \\
\text { Agama KTP } \\
\text { Keimanan dalam ruang kosong } \\
\text { Toleransi searah } \\
\text { Keberagamaan minus keberagaman }\end{array}$ \\
\hline 2. & Sila II & $\begin{array}{l}\text { Nilai kemanusiaan versus } \\
\text { fundamentalisme dan sektarian }\end{array}$ & $\begin{array}{l}\text { Bullying, persekusi, dan menghujat } \\
\text { Radikal } \\
\text { Keadilan dalam kotak } \\
\text { Dukungan kemanusiaan dalam rasa individu dan } \\
\text { kelompok } \\
\text { Harga diri yang kurang berharga }\end{array}$ \\
\hline 3. & Sila III & $\begin{array}{l}\text { Nilai persatuan Indonesia versus } \\
\text { hegemoni komunitas, dan } \\
\text { pesimisme }\end{array}$ & $\begin{array}{l}\text { Orientasi kepentingan pribadi dan kelompok } \\
\text { Cinta etnik } \\
\text { Analogi negara dengan agama }\end{array}$ \\
\hline 4. & Sila IV & $\begin{array}{l}\text { Nilai kerakyatan versus liberalism } \\
\text { dan hegemoni sektarian }\end{array}$ & $\begin{array}{l}\text { Politik identitas } \\
\text { Politik irasional } \\
\text { Politik uang }\end{array}$ \\
\hline 5. & Sila V & $\begin{array}{l}\text { Nilai keadilan sosial versus } \\
\text { kapitalisme, hedonisme, dan } \\
\text { individualism. }\end{array}$ & $\begin{array}{l}\text { Korupsi } \\
\text { Hedonis } \\
\text { Sarana umum yang pribadi } \\
\text { Plagiasi dan kurang etos kerja }\end{array}$ \\
\hline
\end{tabular}

Sumber: Data Hasil Penelitian, 2019. 


\section{b. Peran Negara}

Peran negara tentu direpresentasikan oleh pemerintah. Negara adalah lanjutan dari keinginan manusia yang hendak bergerak antara seorang dengan orang lainnya dalam rangka menyempurnakan segala kebutuhan hidupnya, semakin luas pergaulan manusia serta semakin banyak kebutuhan, maka bertambah besar kebutuhannya kepada suatu organisasi negara yang akan melindungi dan memelihara keselamatan hidupnya (Marpaung, 2018). Negara diharapkan hadir dalam mengurusi hal-hal yang menjadi kepentingan dari semua warganya.

Di dalam implementasinya, negara di era reformasi ini terutama di masa pemerintahan sekarang ini, berupaya hadir dalam menjawab permasalahan-permasalahan yang terjadi di tengah masyarakat. Dalam banyak prosesnya, kegiatan yang dilakukan pemerintah adalah mengikuti prosedur dan amanat dari perundang-undangan. Pelaksanaannya diwujudkan melalui pengeluaran kebijakan yang dapat mendorong suasana kondusif dan peri kehidupan yang membuat masyarakat tenang dan dapat menjalankan aktivitasnya dengan tenang tanpa gangguan yang berarti. Dalam konteks terjadinya situasi yang dapat mengganggu keamanan, misalnya, pemerintah sesuai prosedurnya menurunkan aparat keamanan dari unsur TNI-Polri untuk mengambil langkah-langkah pengamanan. Pemerintah juga menggandeng organisasi sosial dan kemasyarakatan yang dalam hal itu kemudian direspons dengan baik menunjukkan bahwa mereka melihat bahwa langkah pemerintah adalah dalam koridor kepentingan bangsa dan negara serta selaras dengan nilai-nilai bersama. Pada sisi yang lain, dukungan basis organisasi social kemasyarakatan tersebut menjadi bukti keterbukaan dari ideologi Pancasila.

Langkah procedural di bidang kebijakan, pemerintah melakukan revitalisasi Pancasila antara lain melalui implementasi penempatan Pancasila sebagai sumber nilai dasar, nilai instrumental, dan nilai praktis. Regulasi atau perundang-undangan yang dikeluarkan negara merujuk pada Pancasila dan Konstitusi Negara. Secara formal hal seperti itu menempatkan Pancasila sebagai sumber hukum dan nilai yang dipedomani bersama. Seperti diketahui, dalam awal-awal masa reformasi, pembahasan Pancasila mengalami penurunan. Budiyono (2017) menyebut istilah redup untuk pembicaraan tentang Pancasila tersebut. Seiring dengan itu Budiyono menambahkan saat itu bermunculan ideologi transnasional mewarnai gerakan social bernuansa agama yang dampaknya kerap menimbulkan konflik dan kekerasan dan bila sudah begitu baru teringat Pancasila. Dalam konteks itu, pemerintah berupaya menempatkan Pancasila sebagai nilai-nilai bersama.

Di dalam perjalanan era reformasi, terdapat pengeluaran perda yang beraura diskriminatif, kedaerahan, dan tidak sesuai dengan nilai-nilai Pancasila serta UUD 1945. Dalam hal itu negara melalui atribut pemerintah yaitu Mahkamah Agung sesuai kewenangannya dapat menggugurkan atau mencabut peraturan bermasalah tersebut. Bahkan pemerintah kemudian meresmikan Badan Pembinaan Ideologi Pancasila yang diharapkan dapat berperan dalam memasyarakatkan nilai-nilai ideologi Pancasila.

Lalu secara khusus sosialisasi nilai-nilai Pancasila juga dipandang penting diberikan kepada peserta didik karena mereka sebagai calon generasi penerus bangsa. Kekhususan tersebut terlebih-lebih lagi bagi peserta didik di level mahasiswa. Undang-Undang Nomor 12 Tahun 2012 tentang Pendidikan Tinggi mengamanatkan bahwa sistem pendidikan tinggi di Indonesia harus berdasarkan Pancasila dan selain itu kurikulum pendidikan tinggi wajib memuat pelajaran pengembangan kepribadian Indonesia, seperti mata kuliah Pendidikan Pancasila, Pendidikan Kewarganegaraan, Agama, dan Bahasa Indonesia. Efektivitas pembelajaran pembentukan kepribadian keindonesiaan tersebut masih perlu didalami, namun setidaknya kebijakan tersebut menjadi dasar untuk menunjukkan pentingnya nilai-nilai Pancasila. 
Respons pemerintah terhadap nilai-nilai bersama didukung pula dengan penegakan nilainilai instrumental ideologi melalui penegakan hukum. Informasi tentang penegakan hukum dapat dicermati secara luas baik dari media cetak maupun elektronik. Banyak terdengar kabar penangkapan pejabat publik pelaku korupsi seperti kepala daerah dan bahkan juga petinggi negara. Proses peradilannya juga dapat diakses dan diikuti secara transparan. Begitu juga dapat dicermati penangkapan serta penegakan/sanksi hukum bagi pelaku ujaran kebencian, persekusi, dan sindikat terorisme. Ini merealisasikan ungkapan Manan bahwa hukum dalam kehidupan nyata difungsikan sebagai sarana kontrol sosial dalam kehidupan masyarakat (Prabowo, 2015).

Dalam hal ini, secara procedural pemerintah berperan di dalam mengurusi kepentingan warga negara. Apabila dikerucutkan berbagai tantangan globalisasi yang tercermin pada berbagai perilaku sebagian anak bangsa, meski dalam skala kecil namun harus diakui membawa dampak yang sangat luas. Berkembangnya paham radikal dan orientasi sentiment primordial dipahami pemerintah sebagai kondisi yang apabila dibiarkan dapat mengancam eksistensi nilai-nilai kebersamaan dalam keindonesiaan. Upaya pemasyarakatan nilai-nilai ideologi sekarang ini direvitalisasi setelah sebelumnya sempat mengalami devitalisasi. Seperti diketahui, pasca kejatuhan Orde Baru sempat disebut Pancasila menjadi alat yang digunakan rezim untuk pelanggengan kekuasaan. Program massif P4 di era Orde Baru disorot banyak pihak. Parahnya, Pancasila bahkan dituding sebagai sumber permasalahan dalam kehidupan berbangsa dan bernegara. Hal itu bahkan diikuti munculnya polemik tentang Pendidikan Pancasila terkait apakah masih relevan diajarkan di sekolah atau tidak (Hastangka et al., 2019).

Respons pemerintah yang terbilang tegas adalah pengeluaran Peraturan Pemerintah Pengganti Undang-Undang kemudian disahkan menjadi Undang-Undang Nomor 16 Tahun 2017 tentang Ormas. Regulasi tersebut kemudian berimplikasi pada pembubaran Ormas Hizbut Tahrir Indonesia. Organisasi kemasyarakatan ini secara terang-terangan sudah mengumumkan konsep pemerintahan khilafah yang tentu saja tidak sesuai dengan nilai-nilai keindonesiaan dengan Pancasila sebagai ideologi negara. Ketegasan sikap pemerintah tersebut perlu dicatat sebagai bentuk keberanian yang belum tentu dilakukan pemerintah lainnya. Meskipun di awal pemberlakuan terdapat pihak yang kontra, namun pemerintah kemudian dapat meyakinkan masyarakat bahwa regulasi itu benar-benar untuk kepentingan bersama dan sesuai realitanya, organisasi kemasyarakatan yang dibubarkan adalah yang mengembangkan nilai-nilai tidak sesuai dengan keindonesiaan dengan basis nilai ideologi negara. Catatan penting yang dapat dilihat dari situasi ini adalah bahwa pengambilan kebijakan tersebut di tengah situasi pemimpin saat itu dihadapkan dengan persiapan untuk masa pemilihan umum. Kondisi demikian sangat sulit, namun dengan komitmennya Presiden ternyata mengambil langkah berani.

Pengesahan undang-undang anti-terorisme juga dilihat dari peran yang dilakukan pemerintah dalam merawat nilai-nilai bersama. Pengesahan undang-undang tersebut mendapat perhatian khusus karena sebelumnya pembahasan dan rencana pengesahan revisi RUU Antiterorisme sempat menemukan jalan buntu bahkan telah mandek dalam hitungan tahun. Padahal sesuai realitanya aparat penegak hukum di lapangan sudah sangat membutuhkannya untuk menjadi pedoman penanganan masalah terorisme.

Implikasi peran pemerintah terhadap aktualisasi nilai bersama, dari persepsi masyarakat diperoleh respons sangat positif atas berbagai kebijakan dan peran yang telah dilakukan pemerintah. Masyarakat melihat negara hadir dalam memproteksi nilai-nilai bersama. Hal itu menunjukkan penguatan peran pemerintah meskipun secara prosedur sebetulnya hal itu menjadi kewenangan pemerintah. Untuk kasus Indonesia perlu dicatat bahwa seringkali pemimpin tidak berani tegas dalam mengeluarkan regulasi ketika terkait dengan hal-hal yang bersifat "peka" atau yang ada hubungannya dengan identitas primordial tertentu. Namun ketegasan pemerintah 
dalam pengeluaran regulasi seperti undang-undang tentang Ormas dan undang-undang tentang anti-terorisme maupun proses penegakan hukum secara berkeadilan, semakin memperkuat persepsi masyarakat akan nilai-nilai bersama.

Implikasi yang terpenting dari peran pemerintah dalam memproteksi nilai-nilai bersama tersebut, terlihat penurunan eskalasi dan kegiatan yang menjurus pada perilaku yang menonjolkan sentiment primordial. Setidaknya masyarakat secara umum diyakinkan bahwa pemerintahan yang ada cukup konsisten dan tegas dalam merawat nilai-nilai bersama. Masyarakat pun bisa melihat bahwa kebijakan dan ketegasan pemerintah tersebut dilakukan bukan atas dasar sentiment primordial, tetapi justru atas dasar kepentingan bersama sebagai sebuah negara bangsa. Dalam hal ini pemerintah dapat mengajak dan meyakinkan masyarakat untuk menilai kebijakannya dari dasar penilaian umum dan dalam hal ini yaitu dari vested interests (Bertens, 2000). Pada sisi lain, pandangan masyarakat juga telah didasarkan pada pemahaman akan fleksibilitas nilai Pancasila itu sendiri sehingga ikut menstimulus penerimaan peran pemerintah dalam menjaga nilai Pancasila. Masyarakat bisa memahami bahwa nilai-nilai Pancasila dapat mengatasi dinamika keberagaman masyarakat.

Jika melihat secara lebih jauh, implikasi peran pemerintah tersebut tidak kemudian langsung mengakselerasi aktualisasi nilai-nilai ideologi secara lebih signifikan. Implikasinya baru parsial, terutama meredam aktualisasi cara berpikir, sikap, dan perilaku radikal atau nilai-nilai yang menunjukkan sentiment primordial. Ada beberapa alasan untuk itu, antara lain perlunya waktu, dukungan masyarakat, dan perubahan mindset bukanlah pekerjaan yang dapat dilakukan secara singkat. Faktor pemberlakuan regulasi yang belum terlalu lama dan kuatnya pengaruh globalisasi dapat dilihat sebagai pembenaran atas belum signifikannya aktualisasi nilai-nilai Pancasila tersebut.

\section{Simpulan}

Dimensi globalisasi dengan sajian nilai transnasional antara lain dalam bentuk paham sekularisme, individualism, liberalism, radikalisme, individualisme, kapitalisme, komunisme, sosialisme, fundamentalisme, pemerintahan khilafah, dan hegemoni sektarianisme dalam mekanismenya mempengaruhi corak berpikir serta berperilaku masyakat melalui proses interaksi dan tarik-menarik dengan nilai-nilai yang terdapat di dalam sila-sila ideologi Pancasila. Kondisi tersebut mempengaruhi sebagian anggota masyarakat atau warga negara sehingga terdapat aktualisasi nilai yang kurang sesuai dengan nilai-nilai bersama sebagaimana diamanatkan di dalam ideologi Pancasila yang merupakan ideologi negara. Meski hanya sebagian kecil saja dari praktik pola pikir, pola sikap, dan pola perilaku anak bangsa yang tidak sesuai dengan nilai-nilai bersama dalam konteks keindonesiaan, membawa dampak yang dapat berpengaruh serta mengganggu kohesivitas dan integrasi bangsa.

Negara kemudian hadir dalam perannya yang secara konsisten dan tegas dalam merawat nilai bersama melalui pengeluaran kebijakan yang menguatkan nilai-nilai Pancasila dan menganulir kebijakan di daerah yang kurang sesuai dengan nilai-nilai Pancasila, pemberdayaan aparatur sesuai fungsi, pembentukan Badan Pembinaan Ideologi Pancasila, sosialisasi nilai, perangkulan organisasi social kemasyarakatan, dan juga penegakan/sanksi hukum. Peran negara tersebut didukung oleh masyarakat Indonesia dan termasuk di dalamnya direpresentasikan organisasi social kemasyarakatan. Dukungan tersebut menjadi bukti bahwa disadari nilai-nilai Pancasila adalah bersifat terbuka dan merupakan nilai bersama serta bukan kerangka propaganda pemimpin pemerintahan. Peran pemerintah tersebut meski belum dapat langsung mengakselerasi masyarakat untuk mengaktualisasikan nilai-nilai ideologi secara lebih signifikan, namun telah berimplikasi pada timbulnya persepsi positif masyarakat atas penguatan serta hadirnya negara, dan selain itu dapat meredam eskalasi dan kegiatan yang menjurus pada perilaku yang 26 
menonjolkan sentiment primordial. Dalam konteks ini, peran negara didukung dengan komitmen pemimpin pemerintahan untuk merawat nilai-nilai kebersamaan yang terkandung di dalam nilainilai ideologi negara.

\section{Ucapan Terima Kasih}

Ucapan terima kasih disampaikan kepada Rektor Universitas Pertahanan, Dekan FMP, Ketua LPPPM, dan Sesprodi FMP Universitas Pertahanan yang mendukung karya dosen serta memberikan dukungan finansial.

\section{Referensi}

Agus, A. A. (2016). Relevansi Pancasila sebagai ideologi terbuka di era reformasi. Jurnal Office, 2(2), 229238. http://ojs.unm.ac.id/jo/article/download/2958/1608

Asshiddiqie, J. (2006). Ideologi, Pancasila, dan konstitusi. Jaringan Dokumentasi Dan Informasi Hukum, 1, 1-23. jdih.ristekdikti.go.id/?q=system/files/perundangan/1927202140.pdf\%0A

Bertens, K. (2000). Pengantar etika bisnis. Kanisius.

Budiarjo, M. (2017). Dasar-dasar ilmu politik (Rev.). Gramedia.

Budiyono. (2017). Memperkokoh ideologi negara Pancasila melalui bela negara. Citizenship: Jurnal Pancasila Dan Kewarganegaraan, 5(1), 55-63. https://doi.org/http://doi.org/10.25273/citizenship.v5i1.1148

Bunga, M., Maroa, M. D., Arief, A., \& Djanggih, H. (2019). Urgensi peran serta masyarakat dalam upaya pencegahan dan pemberantasan tindak pidana korupsi. Law Reform, 15(1), 85-97. https://doi.org/https://doi.org/10.14710/lr.v15i1.23356

Hastangka, H., Armawi, A., \& Kaelan. (2019). Dampak sosialisasi empat pilar MPR RI terhadap Pendidikan Pancasila di perguruan tinggi. Jurnal Civics: Media Kajian Kewarganegaraan, 16(2), 98-110.

Juneman, Meinarno, E. A., \& Rahardjo, W. (2012). Symbolic meaning of money, self-esteem, and identification with Pancasila values. Procedia - Social and Behavioral Sciences, 65, 106-115. https://doi.org/https://doi.org/10.1016/j.sbspro.2012.11.099

Kaelan. (2004). Pendidikan Pancasila (8th ed.). Paradigma.

Kemala, A. (2018). Globalisasi industri hiburan Jepang dan Korea: Pengaruh terhadap perspektif publik antar negara. Global: Jurnal Politik Internasional, 20(2), 201. https://doi.org/10.7454/global.v20i2.336

Kim, B. J., Kavanaugh, A. L., \& Hult, K. M. (2011). Civic engagement and internet use in local governance: hierarchial linear models for understanding the role of local community groups. Administration \& Society, 43(7), 807-835. https://doi.org/10.1177/0095399711413873

Kiswanto, E. (2005). Negara kesejahteraan (welfare state): Mengembalikan peran negara dalam pembangunan kesejahteraan sosial di Indonesia. Jurnal Kebijakan Administrasi Publik, 9(2), 91-102. https://doi.org/https://doi.org/10.22146/jkap.8320

Li, X., \& Soobaroyen, T. (2020). Accounting, Ideological and Political Work and Chinese multinational operations: A neo-Gramscian perspective. Elsevier. https://doi.org/https://doi.org/10.1016/j.cpa.2020.102160

Mangunsong, N., \& Fitria, V. (2019). Pancasila dan toleransi pada tradisi keagamaan masyarakat Yogyakarta. Jurnal Civics: Media Kajian Kewarganegaraan, 16(1), 89-97.

Marpaung, L. A. (2018). IImu negara. Andi Offset.

Mir, U. R., Hassan, S. M., \& Qadri, M. M. (2014). Understanding globalization and its future: An analysis. Pakistan Journal of Social Sciences (PJSS), 34(2), 607-624.

Muryanti. (2018). Tindakan korupsi sebagai tindakan imoral dalam perspektif fungsional (kajian film korupsi dan kita: rumah perkara). Jurnal Komunikasi Profetik, 11(2), 32-45. https://doi.org/https://doi.org/10.14421/pjk.v11i2.1317

Novenanto, A. (2016). Membangun bencana: Tinjauan kritis atas peran negara dalam kasus Lapindo. 
Masyarakat; Jurnal Sosiologi, 20(2), 159-192.

https://doi.org/https://doi.org/10.7454/mjs.v20i2.4263

Nurwardani, P., Saksama, H. Y., Winataputra, U. S., Budimansyah, D., Sapriya, Winarno, Mulyono, E., Prawatyani, S. J., Anwar, A. A., Evawany, Priyautama, F., \& Festan, A. (2016). Pendidikan Pancasila untuk perguruan tinggi. Ditjen Belmawa.

Ohmae, K. (1994). The borderless world: Power and strategy in the global marketplace. HarperCollins.

Prabowo, M. S. (2015). Pengaruh globalisasi ekonomi dan hukum ekonomi internasional dalam pembangunan hukum ekonomi di Indonesia. Jurnal Litigasi, 16(1), 2741-2780. https://doi.org/http://dx.doi.org/10.23969/litigasi.v16i1.52

Pratiwi, A. E., Triyono, S., Rezkiyanto, I., Asad, A. S., \& Khollimah, D. A. (2018). Eksistensi masyarakat adat di tengah globalisasi. Jurnal Civics: Media Kajian Kewarganegaraan, 15(2), 95-102.

Sanjaya, A. R. (2018). Petisi Indonesia untuk Dunia: Potret Globalisasi Gerakan Sosial Digital. Jurnal Komunikasi, 10(1), 17-32. https://doi.org/http://dx.doi.org/10.24912/jk.v10i1.520

Sassen, S. (2007). A sociology of globalization. W.W. Norton \& Company, Inc.

Setijo, P. (2006). Pendidikan Pancasila: Perspektif sejarah perjuangan bangsa, dilengkapi dengan undangundang dasar hasil amandemen. Gramedia.

Sitorus, J. H. E. (2016). Pancasila-based social responsibility accounting. Procedia-Social and Behavioral Sciences, 219, 700-709. https://doi.org/10.1016/j.sbspro.2016.05.054

Surajiyo. (2018). Kaitan filsafat dengan ideologi: Keunggulan dan ketangguhan ideologi pancasila. Seminar Nasional PPKn 2018, 1-28.

Wells, P., \& Wang, L. (2017). Borderless world 2.0. Evs30 Symposium, December, 1-10.

Winarno. (2014). Paradigma baru pendidikan kewarganegaraan. Bumi Aksara. 